\title{
CECÍLIA MEIRELES: O LIVRO E A PALAVRA INVÍSIVEL ${ }^{1}$
}

\section{CECÍLIA MEIRELES: THE BOOK AND THE INVISIBLE WORD}

Ilca Vieira de OLIVEIRA ${ }^{2}$

\author{
Cada palavra uma folha \\ no lugar certo. \\ Uma flor de vez em quando \\ no ramo aberto. \\ Um pássaro parecia \\ pousado e perto.
}

Mas não: que ia e vinha o verso pelo universo.

(MEIRELES, 2001, p. 1247)

\begin{abstract}
Resumo: Este texto tem como objetivo trazer à luz uma abordagem crítica sobre o processo de criação artística e a relação que o artista estabelece com a sua própria obra. Ou seja, pretende verificar como determinado livro é deixado à margem pelo escritor ao longo de reedições e publicações de sua produção poética. Destaca-se, aqui, a obra Espectros, primeiro livro de poemas de Cecília Meireles, publicado em 1919. Esses poemas jamais foram reeditados durante a vida da autora e, depois de sua morte, somente em edição de 2001, momento em que se comemorou o centenário de nascimento da poeta. Há exatamente 100 anos, a escritora estreou na literatura com essa coletânea de sonetos, os quais foram suprimidos da edição de sua Obra poética, de 1958, por ela própria. Considerando esse ano como centenário de estreia da autora no mundo das letras, a nossa reflexão irá discutir o processo criativo do poeta, o papel do crítico e o do leitor com base da edição da Obra poética, de 1958.
\end{abstract}

Palavras-chave: Cecília Meireles. Espectros. Criação poética. Edição crítica.

Abstract: This paper aims to bring to light a critical approach about the process of artistic creation and the relationship that the writer Cecília Meireles establishes with her own work. In other words, this paper intends to verify how a certain book is left aside by the writer along reissues and publications of his or her poetic production. Espectros, the first book of poems by Cecília Meireles published in 1919 is highlighted here. The poems were not reprinted during Cecília Meireles' life, but only after her death in the 2001, when the centenary of her birth was celebrated. Exactly 100 years ago the writer made her debut in literature with this collection of sonnets, but she decided not to publish them in her 1958 edition Obra Poética (Poetic Work). Considering this year as the centenary of the author's debut in the world of letters, our reflection will discuss the poet's creative process as well as the critic's and the reader's role, based on the 1958 edition of Obra Poética.

Keywords: Cecilia Meireles. Espectros. Poetic creation. Critical edition.

1 Este texto é resultado de pesquisa realizada no período de outubro de 2015 a setembro de 2016, como Bolsista da Capes (Processo BEX 2802/15-5), na modalidade Estágio Sênior no Exterior, na Université Sorbonne Nouvelle - Paris 3, França, e, atualmente, desenvolvida no âmbito do projeto "Cartografias poéticas: os Bichos, a Paisagem e o Jardim", na Unimontes, como parte do projeto CCVRAV - Projeto de Inovação estrutural, técnica e tecnológica com vista à divulgação da memória audiovisual do Norte de Minas. FINEP/UNIMONTES/FAPEMIG.

${ }^{2}$ Professora Titular do Departamento de Comunicação e Letras da Universidade Estadual de Montes Claros e do Mestrado em Letras/Estudos Literários e do PROFLETRAS; Doutorado em Literatura Comparada pela

Universidade Federal de Minas Gerais. E-mail: ilcavieiradeoliveira@yahoo.com.br Revista Graphos, vol. 21, n 2, 2019| UFPB/PPGL | ISSN 1516-1536 
Em 1958, Cecília Meireles publica sua Obra poética, em um volume único pela editora José Aguilar sob a direção de Afrânio Coutinho. Esse volume é organizado da seguinte maneira: "Nota Editorial”, de Afrânio Coutinho; "Introdução geral”, de Darcy Damasceno; "Fortuna crítica”, com apreciações de Mário de Andrade, Osmar Pimentel, Cunha Leão, José Paulo Moreira da Fonseca, Menotti Del Picchia, Nuno de Sampaio, Paulo Rónai e Murilo Mendes; "Notícia Biográfica" e "Reportagem Iconográfica". Sobre a edição do volume, na "Nota Editorial", o crítico Afrânio Coutinho tece o seguinte comentário:

\begin{abstract}
Além dos textos completos da autora, sob rigorosa apresentação, figura ainda na presente edição uma introdução crítica, acrescida de diversos outros testemunhos comprobatórios de sua fortuna crítica, e que analisam a sua poesia, situando-a devidamente na literatura brasileira.

Enriquecem-na ainda um documentário ilustrativo, compreendendo desenhos da própria autora e, como portadas a cada um dos livros, xilogravuras da artista chilena Graciela Fuensalida, especialmente confeccionadas para o volume. Será desnecessário ressaltar o valor dessas gravuras, não somente pelo seu aspecto técnico, senão também pela feliz captação da atmosfera de misteriosa espiritualidade e diáfana beleza da poesia de Cecília Meireles (COUTINHO, 1958, p. x).
\end{abstract}

Coutinho iniciou, em 1958, a sua função de diretor literário da série Biblioteca LusoBrasileira na Editora Aguilar e, nesse cargo, empenhou-se nas edições de vários autores, como se pode ver por essa edição da poesia de Cecília Meireles. Ao examinar o comentário do editor, o que se pode verificar é que há uma preocupação em destacar que a "apresentação", nomeada de "Introdução geral", é de autoria do crítico Darcy Damasceno e que ela foi executada com “rigor". Ou seja, que a apresentação não é uma crítica realizada por amador, nem é uma "crítica de rodapé", muito menos feita por profissional despreparado, pois se trata de um crítico que desenvolve uma análise da obra poética de Cecília Meireles com critério estético e estilístico seguindo a mesma linha do editor ${ }^{3}$. Diante disso, fica explícito, pelo discurso do editor, que o leitor não tem em mãos uma edição ordinária, mas um produto editorial de qualidade, com preparo técnico, seriedade e bem confeccionado em todos os sentidos, desde o estudo crítico que irá conduzir o leitor pela obra poética até a realização gráfica.

Os livros que compõem o volume não são elencados na nota editorial, mas já aparecem na folha de rosto. São eles: Viagem; Vaga música; Mar absoluto e outros poemas; Retrato

\footnotetext{
${ }^{3}$ Afrânio Coutinho viveu nos Estados Unidos de 1942 a 1947, período em que atuou como redator-secretário de seleções e aprofundou seus estudos na Universidade de Columbia. Ao retornar ao Brasil, em 1947, foi nomeado, pelo ministro Clemente Mariani, professor catedrático interino de Literatura no Colégio Pedro II; também atuou como crítico na seção "Correntes Cruzadas", no "Suplemento Literário", do Diário de Notícias do Rio de Janeiro, e publicou os livros: Correntes cruzada (1953), Da crítica e Da nova crítica (1957), além de ter assumido o cargo de editor e diretor literário da série Biblioteca Luso-Brasileira, na editora Aguilar, e de ter organizado a Literatura no Brasil (1955-1959), também da Aguilar. Cf. Coutinho (1968, p. xii).
}

Revista Graphos, vol. 21, n² 2, 2019 | UFPB/PPGL | ISSN 1516-1536 
natural; Amor em Leonoreta; Doze noturnos da Holanda; O aeronauta; Romanceiro da Inconfidência; Pequeno oratório de Santa Clara; Canções; Romance de Santa Cecília; Pistoia, Cemitério Militar Brasileiro; Poesia Inédita; Giroflê Giroflá; Caderno de desenhos.

É importante chamar a atenção do leitor para o primeiro parágrafo da nota do editor:

\begin{abstract}
Reúne este volume da Obra Poética de Cecília Meireles toda a sua poesia até o momento publicada, acrescida de uma parte inédita, selecionada pela autora dentre os seus livros de futuras publicações. Jamais tendo tido uma edição conjunta, as suas tiragens limitadas não correspondem à demanda do grande público (COUTINHO, 1958, p. ix).
\end{abstract}

Apesar de o excerto acima expor claramente para o leitor do volume que ele tem em mãos a poesia da autora "até o momento publicada", verifica-se que "toda a poesia publicada" não corresponde exatamente a todos os livros da autora, porque a seleção é feita apenas a partir de Viagem, de 1939, deixando de fora três livros, como veremos a seguir. Percebe-se, também pelo comentário do editor, que a poeta acompanhou a confecção da edição da Obra poética, quando ele informa que há, no volume, um conjunto de poemas inéditos selecionados por ela. Essa edição também expõe algo importante, que são os desenhos da própria autora, reafirmando ainda mais o trabalho da artista, que acompanhou de perto a edição de sua obra poética.

Nota-se que Cecília Meireles atuou como crítica de sua própria escrita, selecionando as composições a que desejava que o público leitor tivesse acesso em 1958, deixando às margens de sua escrita os livros: Espectros, Nunca mais.... e Poema dos poemas (1923), Balada para El-Rei $(1925)^{4}$, todos publicados antes de Viagem. Embora não seja explicitado, nem na nota editorial nem na introdução, o motivo de esses livros anteriores não fazerem parte do volume, pode-se supor que, talvez, a escritora tenha optado por considerar somente as publicações a partir do texto que foi premiado pela Academia Brasileira de Letras, em 1938 (e publicado em Portugal em 1939).

Em 1919, vinte anos antes de publicar o livro premiado que abre a Obra poética (1958), a poeta já havia publicado seu primeiro livro de poemas, Espectros. Trata-se de uma reunião de dezessete sonetos, com edição reduzida, mas elogiada por críticos da época, principalmente João Ribeiro. O texto "Poesia do sensível e do imaginário", de Darcy Damasceno, que tem papel importante como "Introdução Geral" do volume, chama-nos a atenção para a "filiação estética" da escritora nos parágrafos iniciais que cito, a seguir:

\footnotetext{
${ }^{4}$ Cecília publica ainda livros destinados ao público infantil, os quais também não são incluídos nesse volume de 1958. São eles: Saudação à menina de Portugal. Rio de Janeiro: Real Gabinete Português de Leitura, 1930; A festa das letras (1937), livro que tem como coautor Josué de Castro, o que talvez tenha sido mais um motivo para não ser incluído na edição.
} 
Cecília Meireles surge para a literatura brasileira em 1922, apresentada pelo grupo de escritores católicos que entre 1919 e 1927, através das revistas Árvore Nova, Terra do Sol e Festa, defendiam a renovação de nossas letras na base do equilíbrio e do pensamento filosófico. Seu aparecimento coincide com a eclosão do movimento modernista, do qual pretenderam aqueles escritores representar uma tendência, malgrado a diversidade de pontos de vista no enforcamento do fenômeno literário por parte dos grupos concorrentes.

A aproximação entre Cecília Meireles e os jovens congregados em torno de Tasso da Silveira e Andrade Murici, embora não implicando compromisso de ordem doutrinária, delineava a feição espiritual de sua arte, inspirada em elevado misticismo, e acentuava a comunhão de juízos literários, expressa na admiração por Cruz e Sousa e os poetas simbolistas (DAMASCENO, 1958, p. xi).

O fragmento evidencia o contato que a poeta mantém com esse grupo de escritores católicos que, ainda em 1927, quando surge a revista Festa, possuíam "seu programa mínimo, isto é, pensamento filosófico, tradição e universalidade, contrariavam o liberalismo de ideias, a ruptura com o passado literário e o caráter nacionalizante do movimento modernista" (DAMASCENO, 1958, p. xii). O crítico afirma também que o contato que ela mantém com esse grupo é importante porque "favoreceu a atualização de Cecília Meireles com as novas tendências literárias e do pensamento" (DAMASCENO, 1973, p. 192), mas deixa evidente que ela irá construir o seu próprio caminho, conforme se pode verificar no fragmento abaixo:

No tocante ao aparelhamento métrico, julgavam-se válidos os instrumentos herdados,
a eles juntando-se o verso livre decadentista, cujas qualidades rítmicas o diferençavam
bastante do homônimo proposto pelos modernistas de Klaxon. Isso explica o fato de
que, embora manejando metros tradicionais, Cecília Meireles fosse apontada, quando
da publicação de seus primeiros livros, como exemplo das possibilidades renovadoras
que se atribuía a corrente espiritualista. Mas o estudo acurado de Baladas para El-Rei
e Nunca mais...e Poemas dos Poemas evidenciaria uma natureza artística muito
afinada, ainda, com o movimento simbolista e cujas peculiaridades, se pressagiadoras
de um novo estilo poético, eram-no em favor da artista, que estreava provida de uma
intuição rara em nossas letras, e não à conta do grupo que pertencia (DAMASCENO,
1958, p. xii-xiii).

Nota-se que esse volume não silencia completamente os livros que foram publicados antes de Viagem, como se pode verificar pelo excerto da "Introdução Geral", de Darcy Damasceno, que destaca a importância de Nunca mais....e Poema dos poemas, de 1923 - cuja edição é ilustrada por Fernando Correia Dias, o primeiro marido da poeta - e de Baladas para El-Rei, publicado dois anos depois, em 1925. Esse crítico assume seu papel de leitor e conhecedor da poesia da autora, reconhecendo que a poesia dela se insere em um determinado momento histórico e cultural da literatura brasileira. E, por mais que a edição abra com um livro já premiado, segundo esse crítico, “é a obra que marca um novo estágio da poesia ceciliana e se configura com traços de permanência” (DAMASCENO, 1973, p. 193). 
Como se vê, ele deixa claro que é impossível ler a poesia de Cecília Meireles sem levar em conta os livros que foram publicados antes de Viagem, exatamente porque é neles que encontramos a gênese de um exercício poético. Mas é com esse livro publicado, em 1939, que, segundo Darcy Damasceno, a poesia dela alça seu "voo de liberdade", no sentido criativo, e a poeta conquista um lugar importante na poesia brasileira:

Com a publicação de Viagem o influxo simbolista perderia em relevo externo para traduzir-se em filosofia de vida e comportamento estético. A similitude temática e formal, que ligava Cecília Meireles e os epígonos do Simbolismo, cedeu lugar à pluralidade de motivos e à eleição de certos metros; o vocabulário típico substitui-se por um léxico mais variado, e os preceitos espiritualistas de pensamento filosófico, tradição e universalidade vieram singularmente concretizar-se no menos ortodoxo dos renovadores (DAMASCENO, 1958, p. xiii).

A citação acima refere-se aos dois últimos parágrafos que vão fechar a discussão sobre a filiação estética da poeta. E, após esse comentário, o crítico passa a fazer uma leitura acurada dos livros Baladas para El-Rei e Nunca mais... e Poema dos poemas, enfatizando os aspectos simbolistas recorrentes nos poemas, resultado do contato que a escritora manteve com os poetas franceses e brasileiros. Os dois livros são classificados como neo-simbolistas. Ao longo da análise, evidencia-se que a poeta, apesar de estar afinada com o movimento simbolista, expressa um novo estilo poético na poesia brasileira, sendo possível perceber diferenças marcantes entre os poemas de Baladas para El-Rei e Nunca mais....e Poema dos poemas. Vale ressaltar o comentário que faz o crítico:

Comparado às Baladas para El-Rei, Nunca mais....e Poemas dos poemas representam sensível alteração na arte de Cecília Meireles. É óbvio que não se trata aqui de valores quantitativos, mas de comportamento em face do universo. Se o segundo desses livros vale por uma antecipação de recursos técnicos e amostra da filosofia de vida que iria ditar a forma de convívio entre o poeta e seus semelhantes, o primeiro permanece como obra de raro quilate estético e da maior significação da poesia neo-simbolista.

Embora entremostrando ainda os antigos vínculos espirituais da autora, Nunca mais... desprovia-se do ascético recolhimento, do fluxo sentimental e da enfermiça inquietação da obra precedente, desnudando em seus versos uma alma a que se achegara o desencanto, a renúncia e a indiferença.

A consciência da fugacidade do tempo - mola mestra do lirismo ceciliano aponta pela primeira vez em algumas peças do livro; a consideração da vida como sonho, a melancolia, um toque verlaineano na pintura de ambientes penumbrosos completam a caracterização da temática de Nunca mais... que do ângulo expressivo denota desbastamento da adjetivação, abandono do formulário simbolista e eleição de um fundo léxico no qual podemos ver a gênese da linguagem poética a ser exercida a partir de Viagem (DAMASCENO, 1958, p. xvi).

Em 1973, o crítico Darcy Damasceno preparou a edição Seleta em prosa e verso, de Cecília Meireles, com uma seleção de poemas e vários textos narrativos. A apresentação crítica - "Poesia e prosa de Cecília Meireles" - traz uma informação importante sobre o livro 
Espectros, deixando evidente que a autora havia renegado os versos da estreia já a partir do livro Nunca mais....e poemas dos poemas, "apagando da sua bibliografia o livrinho de estreia" (DAMASCENO, 1973, p. 192). É relevante destacar que, ao contrário do que se pode ler no texto da introdução geral da edição da Obra poética, de 1958, quando ele não faz qualquer análise crítica dos poemas, na edição de 1973, publicada nove anos após a morte da autora, ele já inicia seu texto informando ao leitor sobre a existência do livro Espectros. Mas, pelo discurso do crítico, dando ênfase ao fato de a própria autora tê-lo renegado, percebe-se que esse conjunto de poemas não é tão importante. Veja-se a seguinte a apreciação:

UM LIVRINHO DE SONETOS intitulado Espectros, que a autora renegaria já a partir do livro seguinte, marcou a estreia de Cecília Meireles na literatura. Sua publicação fora estimulada por Alfredo Gomes, então seu professor na Escola Normal, o qual procurou amparar com extenso prefácio a discípula dileta. Osório Duque-Estrada e Basílio de Magalhães, cujas aulas Cecília igualmente frequentara, parece terem influído no gosto da jovem pela feitura de sonetos. A curta idade da poeta, a formação conservadora dos mestres e, principalmente, a generalizada aceitação do Parnasianismo, naqueles tempos, explicam a forma poética adotada na pequena brochura de 1919.

Comparados à onda de versos que crescia nas publicações mundana da época, os decassílabos e alexandrinos de Cecília não se inferiorizavam; mas tampouco eles se distinguiam do comum que nas revistas semanais se imprimia. Que longe estavam aqueles versos de dar a medida de uma sensibilidade predestinada reconhecia-o a própria autora, apagando da sua bibliografia o livrinho de estreia (DAMASCENO, 1973, p. 192, grifos no original) $)^{5}$.

Diante desse comentário, o que se pode observar é que o crítico não reconhece que esse conjunto de sonetos seja relevante como criação poética da autora, o que permite concluir ser por esse motivo que o livro novamente não é analisado juntamente com os outros dois, que também foram cortados da edição de 1958. O crítico situa a escritora na estética modernista, dando notícia de que ela surgiu na literatura brasileira em 1922, sendo apresentada pelo grupo de escritores católicos, conforme já apresentado anteriormente. Mas é somente a última parte da "Introdução Geral", na seção "Notícia biográfica", em que a biografia da poeta é exposta, que traz uma breve notícia da existência de Espectros:

Em 1919, deu a lume o primeiro livro de versos, Espectros, que mereceu elogiosas referências dos críticos, entre os quais João Ribeiro, que assim se pronunciou:

\footnotetext{
${ }^{5}$ Em 1969, ano que se comemora 50 anos de estreia da poetisa no mundo das letras, Darcy Damasceno escreve um texto chamado "Cecília: um cinquentenário", publicado no Jornal do Comércio, Rio de Janeiro, em 23/3/1969. Se, na edição de 1958, ele participou como crítico, fazendo a apresentação geral da Obra poética, em 1973, irá mudar de função, assumindo o papel de organizador de Poesias completas, em nove volumes, pela editora Civilização Brasileira. Constam também dois relevantes textos seus sobre a obra poética de Cecília Meireles: "A estreia de Cecília Meireles" e "A morte, casulo da vida", ambos publicados em edição póstuma no livro $D e$ Gregório a Cecília (Organização de Antônio Carlos Secchin e Iracilda Damasceno. Rio de Janeiro: Edições Galo Branco, 2007).
} 
Com o talento e as qualidades poéticas, aqui reveladas, Cecília Meireles em breve, e sem esforço, poderá lograr a reputação de poeta que de justiça lhe cabe (DAMASCENO, 1958, p. LXXIV).

Pelo que parece ficar sugerido nos seus comentários, principalmente nesse texto escrito após a morte de Cecília Meireles, Darcy Damasceno, que era amigo da autora, conhecia muito bem qual era a opinião dela sobre esse livro de estreia.

Se tomarmos a metáfora do espelho - que aparece desenvolvida em toda a obra literária de Cecília Meireles - e a utilizarmos, aqui, para pensarmos a Obra poética enquanto um conjunto de textos a revelar uma imagem da poesia que a poeta compôs, é possível inferir que essa edição de 1958 expõe uma escrita na qual a autora se reconhece. Por isso, o fato de ter silenciado sobre os livros publicados antes de Viagem evidencia que ela não queria expor uma obra que revelasse uma imagem de poesia que não estivesse de acordo com a sua concepção. Ou seja, ela queria que sua obra reunida não se tornasse um "espelho infiel”.

É importante destacar que, no universo das letras literárias, a poeta utiliza a tinta não só para desenhar o mundo com palavras, mas também para escrevê-lo em imagens. Como exemplo, destaco os desenhos que ela faz para texto "Samba, batuque e macumba: estudos de gesto e de ritmo 1926-1934", de uma conferência proferida em Lisboa em 1934, no Clube Brasileiro. Esses desenhos - não apenas sobre os ritmos do samba, batuque e da macumba, conforme o título revela, como também sobre a indumentária da baiana -, antes publicados em separata no Mundo português, em 1935, são incluídos parcialmente em "Caderno de desenhos" $"$.

Tomando em conta esse viés artístico da escritora, chamo a atenção para o desenho que ela faz de si mesma. Se considerarmos que, em 1958, quando sai essa primeira edição da poesia até ali publicada, momento em que ainda não existem os recursos de editoração de hoje, perceberemos que o livro, cujo projeto gráfico apresenta desenhos da própria autora e da artista

\footnotetext{
${ }^{6} \mathrm{Na}$ página que antecede os desenhos, há o seguinte comentário: "O gênio da raça negra, trazida para o Brasil pela colonização portuguesa, contribuiu para enriquecer a alma popular brasileira e toda uma motivação artística, maravilhosamente expressa nas várias manifestações da arte - música, dança, poesia, folclore./ A fim de ilustrar um trabalho sobre os ritmos do samba, do batuque e da macumba, bem como sobre a indumentária da "baiana", Cecília Meireles compôs os desenhos que adiante se reproduzem, magníficos retratos da contribuição negra ao patrimônio cultural do Brasil, bem como testemunhos felizes da capacidade da poetisa de captar a sensibilidade artística do povo./ Foram gravuras primeiramente editadas como separata do Mundo português (Lisboa 1935)". Já na parte da "Nota editorial", além do comentário de Afrânio Coutinho (1958, p. x), já citado no início deste texto, sobre os desenhos da autora e as xilogravuras da artista Graciela Fuensalida, na sequência ele ainda afirma: "Este volume introduz uma inovação no que concerne à apresentação das gravuras. Para tal, ao editor oferecia-se uma alternativa: ou distribuir as ilustrações numa sequência cronológica acompanhando o texto da introdução críticobiográfica, ou reuni-las num caderno, desta forma à ordem lógica normal, ganhando porém em qualidade gráfica em virtude dos recursos do off-set. Optou-se pela segunda maneira, sob o título de 'Reportagem Iconográfica"'.
} 
Graciela Fuensalida, é ilustrado usando os recursos gráficos do off-set. E o que se percebe visivelmente é que a autora controla o processo de editoração dele.

É nessa edição que encontramos dois poemas, em uma página que é colocada após a "Reportagem Gráfica”, os quais podem ser lidos como epígrafes da Obra poética, ou mesmo como uma espécie de "Portal" dos livros que serão expostos em seguida. Vê-se claramente que a autora assina essa edição, como se pode ler pela página que exponho a seguir:

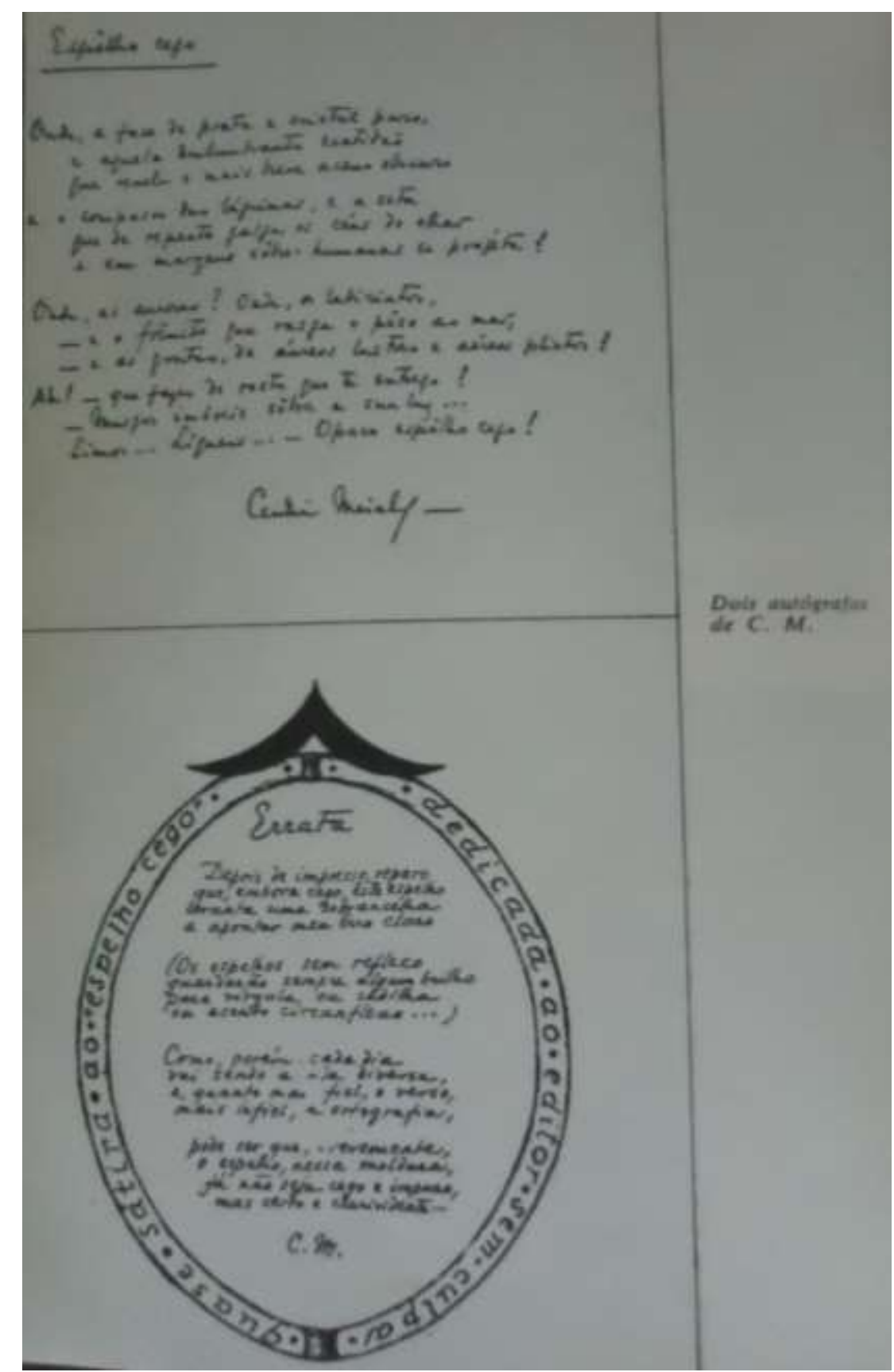

FIGURA 1 - Foto do livro Obra poética (1958)

Fonte: Arquivo pessoal da autora. 
Para facilitar a leitura dos dois manuscritos acima, faço a transcrição dos dois poemas correspondentes, "Espelho cego" e "Errata":

\section{Espelho cego}

Onde a face de prata e cristal puro, e aquela deslumbrante exatidão que revela o mais breve aceno obscuro

e o compasso das lágrimas, e a seta que de repente galga os céus do olhar e em margens sobre-humanas se projeta?

Onde, as auroras? Onde, os labirintos - e o frêmito, que rasga o peso ao mar - e as grutas, de áureos lustres e aéreos plintos?

Ah - que fazes do rosto que te entrego? - musgos imóveis sobre a sua luz...

Limos... líquens... - Opaco espelho cego?

\section{Errata}

Depois de impresso, reparo que, embora cego, este espelho levanta uma sobrancelha a apontar meu erro claro

(Os espelhos sem reflexo guardarão sempre algum brilho para vírgula, ou cedilha ou acento circunflexo...)

como, porém, cada dia vai sendo a vida diversa, e, quanto mais fiel, o verso, mais infiel, a ortografia,

pode ser que, brevemente, o espelho, nessa moldura, já não seja cego e impuro, mas certo e clarividente...

C. M.

(MEIRELES, 2001, p. 1726)

O primeiro poema, "Espelho cego", foi publicado em Dispersos (1918-1964) e é datado de 1954. Na edição de 2001, organizada por Antônio Carlos Seccin, não há qualquer nota explicativa informando ao leitor que esse poema já havia sido publicado anteriormente, isto é, abrindo a Obra poética, de 1958. E pode-se dizer que esse texto figura como assinatura do livro, já que os dois são nomeados pelo editor como "Dois autógrafos de C. M.”.

Em seu exercício poético, Cecília Meireles deixa inúmeros poemas cujo tema é o artista e a escrita da obra, revelando uma nítida consciência crítica, pois deita seu olhar sobre sua 
própria poesia, revelando uma preocupação com a recepção do que escreve e, principalmente, quanto ao leitor ao qual ela será destinada. Os dois poemas-autógrafos são expostos em sua gênese, pois aparecem manuscritos, revelando o processo criador com suas características semióticas - na passagem do estado do manuscrito para a escritura - e, também, abrindo, aqui, uma possibilidade para se pensar a relação entre o texto manuscrito e o entregue ao editor.

O poema "Espelho cego" revela indagações ao longo de toda a sua composição. O eu lírico sugere que as coisas se mostram, se revelam em sua verdadeira face, mas que também podem ser vistas de modo diferente, se o observador se afastar, já que podem se expandir, se esgarçar e se desfazer. Pois, uma coisa é o real, e outra é o imaginário. Há várias indagações do sujeito que escreve diante de sua obra e do outro: Quem eu sou? O que é a minha obra para o leitor? Como o leitor irá ver essa obra que se projeta no livro? E qual é o futuro do livro? Há uma consciência do traço que se esboça para o outro de maneira interrogativa: "Ah - que fazes do rosto que te entrego?". Para quem é direcionada essa pergunta?

Já no poema "Errata”, diferentemente do primeiro manuscrito, há um traço da letra e um do desenho. O poema é escrito dentro do próprio espelho, que aparece desenhado como duplo, pois é espelho e olho. Como se pode observar nessa moldura, há uma inscrição que diz: "Quase sátira ao 'espelho cego' dedicada ao editor sem culpa”. Esse poema expõe uma reflexão sobre a própria Obra poética, como bem evoca o primeiro verso: "Depois de impresso, reparo/ que, embora cego, este espelho/ levanta uma sobrancelha/ a apontar meu erro claro", de um trabalho de escrita com os seus movimentos da mão que escreve e reescreve, e que, mesmo revisando, ainda deixa erros que escapam ao controle do escritor e, quem sabe, ao do editor.

O trabalho do escritor como leitor e crítico da obra envolve uma série de procedimentos, já que uma edição apresenta erros que podem ser revistos. Embora essa frase que consta na borda do espelho seja apresentada como uma dedicatória ao editor sem culpa, ela parece soar não como um elogio, pois que é uma "quase sátira". E o poema "Errata" corresponde a uma correção do que diz o poema "Espelho cego", uma correção que envolve o traço da palavra e o desenho exposto. Desse modo, Cecília Meireles justifica o sentido dos autógrafos e faz do manuscrito - qualquer que seja o traço gráfico: letra, curva, linha, moldura - o desenho do seu pensamento. Desenho este que não deve ser entendido como um espelho, mas como o movimento do pensamento poético, de uma escritora que admite a escrita como um jogo que não existe sem os diálogos com os leitores. O escritor escreve para ser lido, e a obra não existe sem o leitor. Ao tratar de "O leitor ainda futuro", Maurice Blanchot destaca que: 
virá a ser, uma vez feita a obra, poder e possibilidade de ler, já está presente, sob formas variáveis, na gênese da obra. Na medida em que escrever é subtrair-se com maior ou menor dificuldade à impossibilidade, em que escrever passa a ser possível, escrever assume então as características da exigência de ler, e o escritor torna-se a intimidade nascente do leitor ainda infinitamente futuro (BLANCHOT, 2011, p. 216217).

O espelho, como objeto simbólico que abre o volume, não é aqui uma referência sem significado, possibilitando-nos estabelecer uma relação com o mito de Narciso, que ao ver a sua imagem refletida não compreende tratar-se dele mesmo e irá indagar-se diante da imagem: "Por que me foges?". Qual é, no fundo, essa imagem que a obra expõe ao leitor? A obra como espelho que projeta uma imagem do poeta é realmente o que se deseja? Pelas indagações do poema "Espelho cego", não é o isso que Cecilia revela. Os versos evocam uma angústia do eu que escreve em não saber qual é a imagem que o outro vê. O poema explicita uma noção de permanência, com indagações profundas de um eu que tem consciência de que a sua obra irá sobreviver porque os versos são "pássaros libertos" que pousam em outras ramas. Esta reflexão a respeito do espelho revela o desdobramento do eu que, através do "espelho", reconhece a incompletude, a efemeridade e a brevidade da vida. Existindo a identificação do eu com a transcendência, pois as palavras sofrem as transformações como os seres da natureza.

Considerando a reflexão sobre a obra e a sua recepção futura, destacada nos dois poemas por meio do espelho como cego, é possível perceber que, em "Errata”, há uma composição que se elabora sem indagações, como se vê em "Espelho cego". E vemos que o desenho e a letra traçam um sentido diferente para a obra ao revelar que: "pode ser que, brevemente, / o espelho, nessa moldura, / já não seja cego e impuro, / mas certo e clarividente...”. E não é sem sentido que, ao final da Obra poética, surge como ilustração da seção "Caderno de desenhos" a imagem da cegonha com a inscrição a seguir: "EX-LIBRIS/Cecília Meirelles/.....Como uma cegonha que/sonha, que sonha e sonha..." 


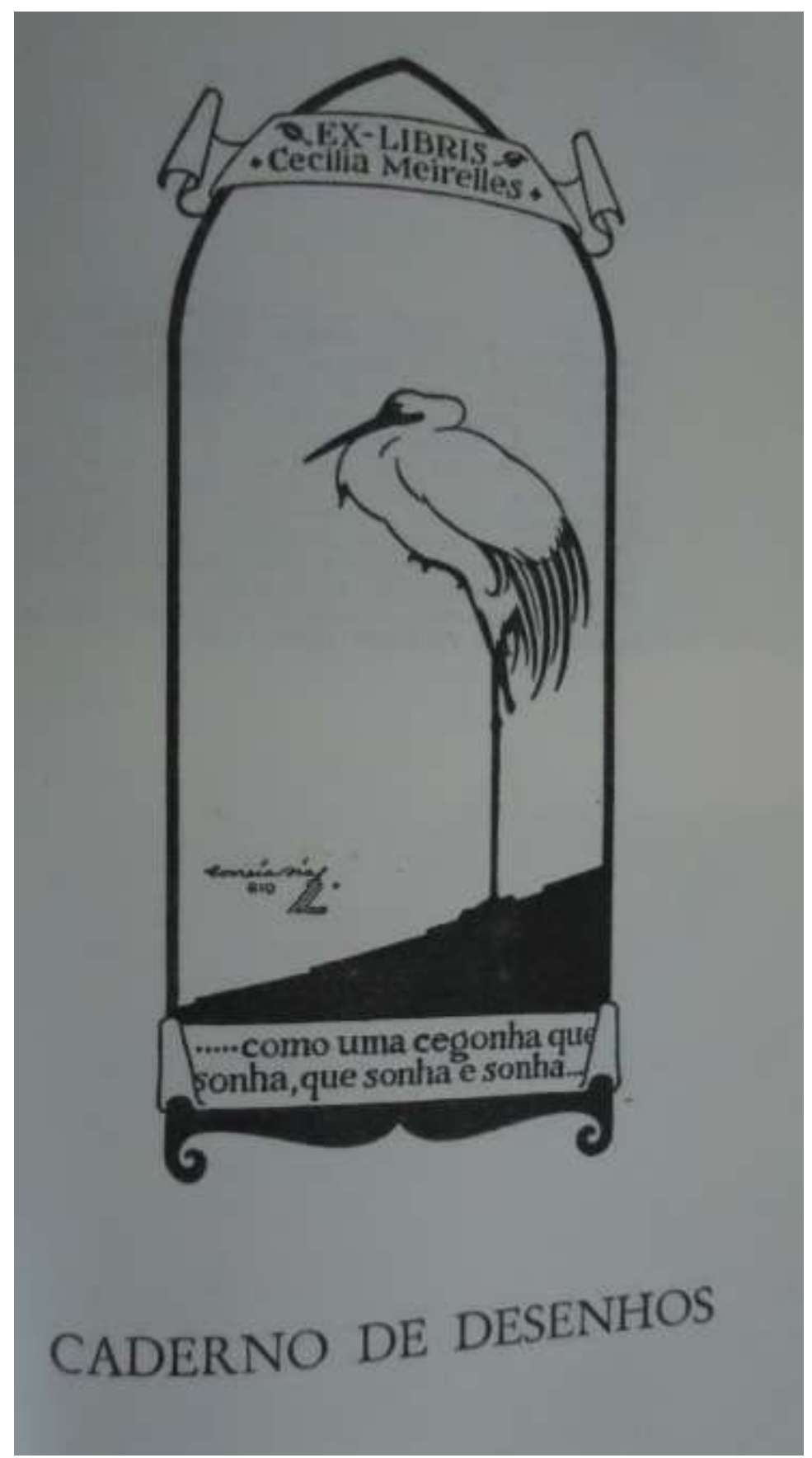

FIGURA 2 - Foto do livro Obra poética (1958).

Fonte: Arquivo pessoal da autora.

O desenho da Cegonha que sonha, como ex-libris, indica o proprietário da obra, que é Cecília Meirelles. O leitor poderá verificar que o nome ainda está escrito com dois "l”, indicando o seu nome civil. Considera-se um traço marcante da identidade autoral, pois a poeta irá retirar um "l" do nome para assinar sua obra. Nota-se que a supressão de um "l" do nome civil já consta quando Cecília publica Viagem em 1939. O pássaro evocado é símbolo de fertilidade e anuncia bom presságio, além de também figurar como símbolo de imortalidade e longevidade no Oriente. Assim, a imagem do pássaro traduz a liberdade e o voo. E o poeta é 
esse ser que contempla sua obra e sonha com a imortalidade dela. Palavra e desenhos revelam a sua força, deixando evidente a imaginação do poeta que entra na pele do pássaro que sonha. Gaston Bachelard (2005, p. 110), ao tratar da imagem do ninho na poesia, destaca que "O ninho, como toda imagem de repouso, de tranquilidade, associa-se imediatamente à imagem da casa simples. Da imagem do ninho à imagem da casa, ou vice-versa, as passagens só se podem fazer sob o signo da simplicidade".

Considerando essa ilustração da cegonha, é possível associar a imagem do poeta, ser pensante, ao pássaro fértil e sonhador, e a imagem do ninho à poesia. O poeta faz-se pássaro fértil, e sua poesia é canto que encanta o leitor.

Essa reflexão sobre o processo criativo e o destino da obra também pode ser encontrada nos versos do poema: "Para onde é que vão os versos", texto escrito dois anos após a publicação da Obra poética.

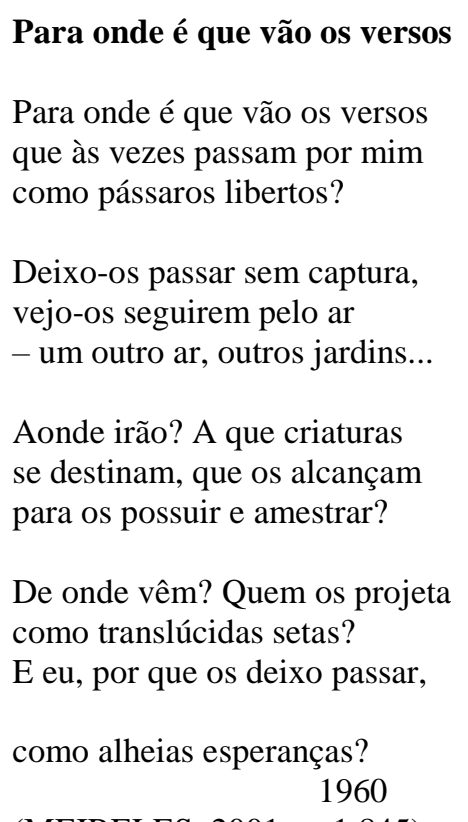

(MEIRELES, 2001, p. 1.845)

O livro Espectros é reeditado em 2001, na edição comemorativa do centenário de nascimento da autora, ou seja, o texto sai do silêncio que a ele foi destinado pela própria poeta e também por vários críticos, que não reconheceram qualidade estética nos poemas e que viram nele somente um valor documental, como expõe Antonio Carlos Secchin, organizador da edição:

Esta é a primeira publicação que deseja apresentar toda a obra da poeta em sua sequência (tanto quanto possível) cronológica, a fim de que o leitor possa acompanhar o desdobramento do projeto criador de Cecília. De início, um obstáculo se antepunha: como tratar dos livros iniciais, ausentes da compilação feita em vida da autora? Manter a exclusão? Agrupá-los em "apêndice"? Não; optamos por inseri-los junto às demais publicações, baseados no fato de que, em algum momento, correspondem à "verdade 
poética" de Cecília, e não havia por que sonegar essa etapa ao conhecimento público. Merece especial destaque a reedição de Espectros, obra de estreia da autora, lançada em 1919, e que, fiel ao nome, parecia ter-se "desmaterializado". Agora, mais de oitenta anos depois, pela primeira vez se reedita essa coletânea, de extraordinário valor documental. Fique claro, porém (e isso se aplica também aos "Dispersos", na Parte II), que a autora validava irrestritamente apenas a sua poesia a partir de Viagem (1939), apesar de vários críticos enxergarem méritos na produção anterior a esse período (SECCHIN, 2001, p. xviii).

O comentário de Antonio Carlos Secchin, que tem um papel importante na preparação dessa edição, ao considerar esse livro de estreia da poeta somente como documento, segue a mesma linha de pensamento de outros críticos que, durante muitas décadas, não reconheceram a poesia escrita e publicada por ela antes de Viagem.

Entre a primeira organização da obra poética completa de Cecília Meireles, em 1958, cuja edição, como vimos, foi acompanhada pela própria escritora, e a versão de 2001, ano de comemoração de centenário de nascimento, organizada por Antônio Carlos Secchin, há mudanças significativas. Destacam-se, ainda, as supressões dos textos críticos publicados em resenhas de jornais de importante circulação e também de duas partes: a introdução geral "Poesia do sensível e do imaginário", de Darcy Damasceno -, e o epílogo - "Guia do leitor do Romanceiro da Inconfidência", de João Gaspar Simões. Ocorreu também a retirada das xilogravuras de Graciela Fuensalida e os desenhos da própria autora, que constavam no final do volume e cujo conjunto era nomeado como "Caderno de desenhos" (já citado anteriormente). São mudanças que o organizador dessa nova edição imprime ao texto formatado em Poesia completa, volumes 1 e 2. Esse projeto realizado em 2001 apaga o projeto artesanal que foi engendrado pela autora e pelo então editor em 1958.

O comentário de Antonio Carlos Secchin também revela a opção de uma prática editorial interessada em que o leitor contemporâneo tenha acesso a toda a produção poética de Cecília Meireles nesse ano de comemorações. Trata-se de um desejo de apresentar "toda a obra da poeta", sugerindo que todos os poemas escritos e publicados por ela estariam nesses dois volumes. Diante disso, o que se pode observar é que o organizador não informa ao seu leitor que essa "poesia completa" ainda poderia estar incompleta, ou seja, não fala sobre a possibilidade de existência de poemas dispersos em cartas e jornais, que não tenham constado em coletâneas e, muito menos, nos espólios da escritora sob a guarda da família ${ }^{7}$.

\footnotetext{
${ }^{7}$ Destaca-se o poema "Romance das donas de Portugal", publicado em 31 de outubro de 1931, na revista Lusitania, da colônia portuguesa no Rio, texto nunca inserido em nenhum livro da poeta. Esse texto foi descoberto pelo pesquisador Ulisses Infante e revelado no artigo "Poema de Cecília dedicado às mulheres portuguesas", publicado no jornal Correio Brasiliense, 10/3/2016.
}

Revista Graphos, vol. 21, n² 2, 2019 | UFPB/PPGL | ISSN 1516-1536 
Essa mesma edição de 2001 já apresenta também uma análise de alguns poemas do livro “invisível”, Espectros. Em “Cecília Meireles e o tempo inteiriço”, Miguel Sanches Neto (2001, p. XXVI) faz o seguinte apontamento sobre o livro: "Ele antecipa as características da poética de Cecília, o que é uma prova de que o livro, mesmo escrito num tom um tanto colegial, já apresentava em gérmen a grande escritora, justificando sua leitura hoje".

Vale acrescentar que, nesse mesmo período que o livro é retirado do silêncio nessa edição comemorativa, foi publicada em Lisboa uma pesquisa consistente sobre a poesia de Cecília Meireles. Trata-se do estudo Cecília Meireles - uma poética do "eterno instante”, tese defendida pela açoriana Margarida Maia Gouveia em 1993 e publicada em 2002. Em sua abordagem analítica, aponta que, durante a escrita da tese, teve acesso somente a excertos do livro Espectros e acrescenta em uma nota de rodapé que, durante a preparação do texto para o formato de livro, pôde consultar os poemas reeditados em 2001.

Em seu estudo, fez análise de alguns sonetos e, ao tecer comentário sobre o soneto “Antônio e Cleópatra”, já finalizando a exposição, acentua que "Embora não dotado de originalidade, este soneto demonstra nesta jovem poetisa de 18 anos um virtuosismo estilístico notável e um desejo de perfeição que caminhará da forma para o conteúdo" (GOUVEIA, 2002, p. 85) e acrescenta em nota de rodapé: "Talvez a rejeição desta obra se deva a este desejo de perfeição que abandona o frívolo culto meramente formal e exige mais da poesia a busca da essência humana" (GOUVEIA, 2002. p. 85). Esse desejo de perfeição parece ser atingido com o livro Viagem. Observa-se que a autora irá revisitar a introdução geral "Poesia do sensível e do imaginário", de Darcy Damasceno:

\footnotetext{
Viagem vale pela revelação definitiva de uma natureza artística em sua plenitude e de um estilo poético em seu ponto de perfeição. Na linha compreendida entre esse livro e Retrato natural exibe-se um painel temático de rara amplitude em nossa poesia moderna. A pluralidade de assuntos diz bem do interesse humano da autora e contraria juízos nem sempre decorrentes de acurado exame da obra poética; do mesmo modo, as mais humildes manifestações da vida, dos seres mais diminutos, os episódios mais singelos são motivo de elevada reflexão por parte de quem, sustentado por exigente filosofia, busca lição de vida (DAMASCENO, 1958, p. XVIII-XIX).
}

Registre-se que essa edição comemorativa será importante para os estudos críticos que surgirão após 2001, entretanto, a produção poética da autora é considerada como "poesia imatura", como se pode verificar no estudo Pensamento e "lirismo puro" na poesia de Cecília Meireles, de Leila Vilas Boas Gouvêa, texto original como tese de doutorado defendida em 2003 na Universidade de São Paulo e publicado em 2008. Na introdução do seu estudo a autora faz o comentário: 
No primeiro capítulo, empreendo uma revisita à poesia imatura ceciliana compreendida pelos livros Espectros, Nunca Mais... e Poemas dos poemas e Baladas para El-Rei, escritos entre dezesseis e aos 21 anos -, onde se sobressai a dicção paranaso-simbolista e neo-simbolista, procurando resgatar as primeiras "presenças fecundantes" nessa lírica e dar algumas respostas a algumas incógnitas renitentes sobre a personalidade literária (GOUVÊA, 2008. p. 22).

É como “poesia imatura" que os livros publicados antes de Viagem serão analisados pela estudiosa. O apontamento, acima, endossa leituras críticas sobre a obra de Cecília Meireles da década de 1970, principalmente no texto Poesia e estilo de Cecília Meireles (a pastora de nuvens), de Leodegário A. de Azevedo Filho: “Viagem, livro que assinala a sua maturidade poética, nos deixa ainda a certeza de que o tempo tudo desmancha, num clima de melancolia e de espiritualidade, marcado pela riqueza de original substrato imaginístico, onde perpassa doce e suave musicalidade" (AZEVEDO FILHO, 1970, p. 43). Conforme se vê pelo comentário do crítico, é com Viagem que a poetisa atinge a "maturidade poética", adquirindo uma dicção própria, com uma poesia que revalorizava o sistema versificatório, com reflexões filosóficas e indagações sobre a brevidade da vida. É perceptível a descrença religiosa; a consciência do poeta no mundo e o processo criativo são matérias de constantes reflexões e indagações nas composições líricas.

Por mais que a crítica sobre a poesia de Cecília Meireles reconheça o mérito dos poemas desse livro de estreia, os estudiosos são claros em afirmarem que as composições são imaturas porque o processo criativo da poetisa ainda estava preso à dicção "parnaso-simbolista e neosimbolista” e que a sua maturidade poética será alcançada somente com Viagem.

Espectro é um livro que não se "desmaterializou" e, por mais que a autora "validasse" somente sua poesia a partir do livro Viagem, de 1939, o que é relevante destacar é que as composições anteriores trazem em si a gênese de uma série de temas que serão desenvolvidos em todo o projeto poético. Dessa forma, esse livro de estreia, que é silenciado pela escritora, não será apagado de sua produção poética, principalmente no que toca ao tema do "fantasma", da sombra e da morte dos seres vivos da natureza.

Por mais que o escritor exerça um controle em relação à sua obra poética, ele reconhece a impossibilidade de controle absoluto, pois seus poemas são como flores que se libertam da árvore e atingem a dimensão da imaterialidade. Como todo poeta moderno, Cecília Meireles exprime um processo criativo extremamente reflexivo, como se vê nas indagações dos versos expostos em poemas, citados acima. Há um eu que se coloca diante da obra como um sujeito fragmentado e inacabado, com várias "faces". A poesia lírica ramifica-se, e o poeta consciente do ato criativo reconhece que a poesia é "flor" que irá se dissolver como todas as coisas do mundo. A condição do poeta diante de sua obra é de:

Revista Graphos, vol. 21, n 2, 2019 | UFPB/PPGL | ISSN 1516-1536 


\title{
Renúncia
}

Rama das minhas árvores altas, deixa ir a flor! que o tempo, ao desprendê-la, roda-a no molde de noites e de albas onde gira e suspira cada estrela.

Deixa ir a flor! deixa-a ser asa, espaço, ritmo, desenho, música absoluta, dando e recuperando o corpo esparso que, indo e vindo, se observa, e ordena, e escuta...

Falo-te, por saber o que é perceber-se. Conheço o coração da primavera, e o dom secreto do seu sangue verde, que num breve perfume existe e espera.

Verti para infinitos desamparos tudo que tive no meu pensamento.

Era a flor dos instantes mais amargos.

Por onde anda? No abismo. Dada ao vento...

(MEIRELES, 2001, p. 260)

Se a obra poética é uma "rama", com suas flores-livros, e as pétalas são os poemas, os poemas como pétalas desfolhadas que vão sendo levadas pelo vento, e as flores com seu pólen que é levado pelas abelhas quando alçam voo. Cecília Meireles, em seu processo reflexivo sobre a poesia, o poema e o leitor, expõe uma imagem da "palavra" poética como "pássaros", como se pode ler no poema a seguir:

\section{Voo}

\section{A Darcy Damasceno}

\author{
Alheias e nossas \\ as palavras voam. \\ Bando de borboletas multicores, \\ As palavras voam. \\ Bando azul de andorinhas, \\ bando de gaivotas brancas, \\ as palavras \\ como águias imensas. \\ Como escuros morcegos \\ como negros abutres, \\ as palavras voam. \\ $\mathrm{Oh}$ ! alto e baixo \\ em círculos e retas \\ acima de nós, em redor de nós \\ as palavras voam.
}

$\mathrm{E}$ às vezes pousam.

(MEIRELES, 2001, p. 1951-1952)

No primeiro verso, ao nomear as palavras como "alheias e nossas", revela uma definição do processo criativo, pois o poeta "fala de coisas que são suas e de seu mundo, mesmo quando 
nos fala de outros mundos", como acentua Octavio Paz (1996, p. 55). As palavras revelam o homem em sua condição existencial. "A experiência poética não é outra coisa que a revelação da condição humana, isto é, desse transcender-se sem cessar no qual reside precisamente a liberdade essencial" (PAZ, 1996, p. 57). O poeta está sempre em diálogo com outros poetas; sua obra será completada e vivida por um leitor novo, que dará continuidade à obra. Essas contradições, evocadas pela figuração dos animais que voam, podem ser leves como as "borboletas multicores", trazendo leveza, beleza e harmonia, mas podem ser sombrias como os morcegos e os abutres. As palavras apresentam dualidade e alçam voo, e a poeta não tem mais domínio sobre elas. Os poemas são pássaros em movimento, e é difícil para o criador mantêlos presos em gaiolas. Quando "pousam”, podem ser apreendidos pelos leitores e, assim, vão adquirindo novos sentidos e projetando novas imagens, mesmo que seja em um “espelho cego". O poeta busca a permanência em sua obra, porque toma consciência da impermanência das coisas no mundo material. Esse livro, publicado em 1958, não está fechado ao mundo, pois muitos outros livros e outras edições da poesia da autora ainda estão por vir.

\section{Referências}

AZEVEDO FILHO, Leodegário A. de. Poesia e estilo de Cecília Meireles (a pastora de nuvens). Rio de Janeiro: Livraria José Olympio, 1970.

BACHELARD, Gaston. A poética do espaço. Tradução de Antonio de Pádua Danesi. São Paulo: Martins Fontes, 2005.

BLANCHOT, Maurice. O espaço literário. Tradução de Álvaro Cabral. Rio de Janeiro: Rocco, 2011.

COUTINHO, Afrânio. Nota editorial. In: MEIRELES, Cecília. Obra poética. Rio de Janeiro: José Aguilar, 1958, p. IX-X.

COUTINHO, Afrânio. A tradição afortunada (o espírito de nacionalidade no crítico brasileiro). Rio de Janeiro/São Paulo: José Olympio/Editora da USP, 1968.

DAMASCENO, Darcy. Poesia do sensível e do imaginário. In: MEIRELES, Cecília. Obra poética. Rio de Janeiro: José Aguilar, 1958. p. XI-XLII.

DAMASCENO, Darcy. Poesia e prosa de Cecília Meireles. In: MEIRELES, Cecília. Seleta em prosa e verso. Seleção, notas e apresentação de Darcy Damasceno. Rio de Janeiro: Editora José Olympio, 1973. p. 192-203.

GOUVÊA, Leila V. B. Pensamento e "lirismo puro" na poesia de Cecília Meireles. São Paulo: Editora da Universidade de São Paulo, 2008. 
GOUVEIA, Margarida Maia. Cecília Meireles - Uma poética do "Eterno Instante". Lisboa: Imprensa Nacional-Casa da Moeda, 2002. (Escritores dos Países de Língua Portuguesa 27).

INFANTE, Ulisses. Poema de Cecília dedicado às mulheres portuguesas é descoberto. Correio Brasiliense, "Seção Diversão e Arte", 10/3/2016. Disponível em: https://www.correiobraziliense.com.br/app/noticia/diversao-earte/2016/03/10/interna_diversao_arte,521440/poema-de-cecilia-meireles-dedicado-asmulheres-portuguesas-e-descobert.shtml . Acesso em: 1 ago. de 2019.

MEIRELES, Cecília. Obra poética. Rio de Janeiro: José Aguilar, 1958.

MEIRELES, Cecília. Seleta em prosa e verso. Seleção, notas e apresentação de Darcy Damasceno. Rio de Janeiro: Editora José Olympio, 1973.

MEIRELES, Cecília. Poesia completa. Organização de Antônio Carlos Secchin. Rio de Janeiro: Nova Fronteira, 2001. 2v.

MEIRELES, Cecília. Batuque, samba e macumba: estudos de gesto e de ritmo 1926-1934. 2. ed. São Paulo: Martins Fontes, 2003.

PAZ, Octavio. Signos em rotação. Tradução de Sebastião Uchoa Leite. Organização e revisão de Celso Lafer e Haroldo de Campos. São Paulo: Perspectiva, 1996.

SANCHES NETO, Miguel. Cecília Meireles e o tempo inteiriço. In: MEIRELES, Cecília. Poesia completa. Organização de Antônio Carlos Secchin. Rio de Janeiro: Nova Fronteira, 2001. v.1. p. XXI-LIX.

SECCHIN, Antônio Carlos. Apresentação. In: MEIRELES, Cecília. Poesia completa. Organização de Antônio Carlos Secchin. Rio de Janeiro: Nova Fronteira, 2001. v.1. p. VIIXIX. 